\title{
Constraints Faced by Farmer's towards Value Addition in Horticulture and Vegetable Crops
}

\author{
Sonia Rani*, P.S. Shehrawat and Joginder Singh Malik \\ Department of Extension Education, CCS Haryana Agricultural University, \\ Hisar - 125004 (Haryana), India \\ *Corresponding author
}

\begin{tabular}{|l|}
\hline Key w o r d s \\
$\begin{array}{l}\text { Constraints, Farmer } \\
\text { and Losses }\end{array}$ \\
\hline Article Info \\
\hline $\begin{array}{l}\text { Accepted: } \\
\text { 15 September } 2019 \\
\text { Available Online: } \\
\text { 10 October } 2019\end{array}$ \\
\hline
\end{tabular}

\section{A B S T R A C T}

The present study was conducted in Haryana state and two districts Hisar from southwest and Sonipat from northeast were selected, purposively. From each district, three blocks were selected randomly. Further, three villages were selected from each block making a total of 18 villages. From each village, ten farmers were selected randomly, making a total sample of 180 farmers. Hence, one hundred eighty farmers were interviewed for the study. It was found that 'Biological: Consumption of produce by rodents, birds, monkeys' was considered very serious constraint in primary causes of losses of value addition in horticulture and vegetable produce by the respondents and ranked $\mathrm{I}^{\text {st }}$ with weighted mean score of 2.75. It was revealed that 'Inadequate storage facilities' was ranked $\mathrm{I}^{\text {st }}$ and was found with serious causes according to weighted mean score of 2.61. It was shows that 'Harvest: The separation of the commodity from the plant that produced it' was ranked I ${ }^{\text {st }}$ as per weighted mean score of 2.39. It was found that 'Temperature: In general, the higher the temperature, the shorter the storage life of crops' was ranked I ${ }^{\text {st }}$ as per weighted mean score of 2.66. It was revealed that 'Water excess increases the susceptibility to physical damage in some products' was ranked I ${ }^{\text {st }}$ as per weighted mean score of 2.08. To reach the results aggregates total was calculated for each statement separately and on the basis of calculated scores, mean scores and mean score percentage were obtained which were ranked according to their maximum to minimum mean score percentage for assessing the knowledge level of the farmers.

\section{Introduction}

Fresh horticultural produce is highly perishable with some estimates suggesting a post-harvest loss of between (30-50\%) in fruits and vegetables. The losses are due to poor preproduction and post-harvest management as well as lack of appropriate processing and marketing facilities. These losses have several adverse impacts on farmer's income, consumer prices and nutritional quality of the produce. Prices of seasonal horticultural crops fluctuate greatly and during the period of maximum availability the prices are not remunerative to the farmer. At other times these commodities are so 
highly priced that the ordinary consumers find them beyond their purchasing power. Another problem is that fruits and vegetables are not uniformly available and some areas suffer from inadequate supply even when there is a glut in other parts. At present, there is considerable gap between the gross production and net availability of fruits and vegetables due to heavy post-harvest losses (Atanda et al., 2011).

Globally, has been a tremendous increase in the growth of urban population in the recent time. The situation in India is no different. Indian cities are home to an estimated 340 million people, almost equivalent to 30 per cent of the total population. As evident in majority of the industrialized countries, India is experiencing a shift over time from a largely rural and agrarian population residing in villages to urban, non-agriculture centres. Vegetable cultivation has become highly commercialized. But still there is a wide gap between current production and potential productivity. Innovative agricultural technologies that can increase food security in the developing world while conserving environmental resources do exist; yet the global difficulty is getting the appropriate and timely information to farmers. Fruits and vegetables typically constitute an essential part of the daily diet in India and they are in great demand round the year from most sections of the population. The commercial value of fruits and vegetables in terms of direct consumption, processing as well as trade has risen substantially in recent years (Kapoor, 2012).

The producers and the consumers often get a poor deal and the middlemen control the market, but do not add much value. There is also massive wastage, deterioration in quality as well as frequent mismatch between demand and supply both spatially and over time. Since vegetables are perishable in nature, lack of efficient marketing system and appropriate infrastructure results in huge post-harvest losses. Further, non-availability of improved and good quality seeds reduces the profitability and increases production risk (Subbanarasiah, 1991).

\section{Materials and Methods}

\section{Locale of the study}

The present study was conducted in Haryana state and two districts Hisar from south West and Sonipat from north East were selected purposively. Further, three villages were selected from each block making a total of 18 villages. From each village, 10 farmers were selected randomly, making a total sample of one hundred eighteen farmers. Hence, 180 farmers were interviewed for the study. Three blocks from each district i.e. Hisar and Sonipat were selected, purposively. From Hisar, three blocks namely, Hisar I, Hisar II and Adampur, and from Sonipat, blocks Ganaur, Gohana and Murthal were selected, randomly. Thus, six blocks were selected for the study. Out of the six selected blocks, two villages from each block were selected randomly. Thus, a total number of 18 villages, namely, Dobhi, Dhiranwas and Ladwa from block Hisar I, Saharwa, Chiraud and Talwandi Rukka from block Hisar II and Kherampur, Kohli and Siswal from block Adampur, while Bain, Chirsmi and Mohamadpur Majra from Ganaur, Jagsi, Riwara and Baroda Thuthan from Gohana block and Makimpur, Dipalpur and Paldi from Murthal block were selected randomly also.

\section{Collection of data}

For assessing the knowledge, constraints, prospects, training need and perception impact data were collected by conducting personal interview with the respondent at their home/working center. The interview of every 
individual was taken separately so that the others did not influence the answers. In order to measure the knowledge level of farmers they were asked to reply as set of questions on selected of value addition in horticultural and vegetable crops. The scores so obtained were placed under three categories on the basis of knowledge they possessed i.e. 'full', 'partial' and 'no knowledge' weightage given to these response categories was 3, 2 and 1 respectively. Aggregate total was calculated for each constraint separately and on the basis of calculated scores, mean scores and weighted mean score percentage were obtained which were ranked according to their maximum to minimum mean score percentage for assessing the seriousness of constraints. The maximum weighted mean score percentage so obtained was given the rank $1^{\text {st }}$ and the next subsequent one was given the rank $2^{\text {nd }}$ and so on the descending order.

\section{Analysis of data}

The information collected through the responses of the respondents, was suitably coded, tabulated and analyzed to draw meaningful inferences by using statistical tools such as frequency distribution, percentages, weighted mean scores, rank order, correlation and regression.

\section{Results and Discussion}

\section{Constraints perceived by respondents regarding value addition in horticultural and vegetable produce}

Considering the objectives of the study, an effort was made in the present study to find out the constraints faced by the fruit and vegetable growers. According to their frequency, total weighted mean score and after that weighted mean score and constraints per cent were calculated and rank order was assigned. Farmer's perception regarding constraints was marked, analyzed and presented under the following sub-head:

\section{Primary causes of losses}

Table 1 revealed that 'Biological: Consumption of produce by rodents, birds, monkeys' was considered very serious constraint in primary causes of losses of value addition in horticulture and vegetable produce by the respondents and ranked $\mathrm{I}^{\text {st }}$ with weighted mean score of 2.75, followed by 'Microbiological: Damage to stored produce by fungi and bacteria' which was ranked II $^{\text {nd }}$ in order with weighted mean score of 2.35. However, 'Mechanical: bruising, cutting and excessive pooling or trimming of horticultural product causes of loss' was ranked III ${ }^{\text {rd }}$ having weighted mean score of 2.21 .

The data revealed that the cause 'Chemical : Contamination of produce with harmful chemicals such as pesticides or obnoxious chemicals such as lubricating oil' was ranked IV $^{\text {th }}$ according to weighted mean score of 2.07, 'Physical : Excessive or insufficient heat or cold can spoil foods' was ranked $\mathrm{V}^{\text {th }}$ as per weighted mean score of 1.93, 'Biochemical reactions : A number of enzyme-activated reactions can occur in produce in storage' were ranked $\mathrm{VI}^{\text {th }}$ with weighted mean score of 1.90, Physiological : Natural respiratory losses e.g. ethylene results in premature ripening of certain crops ranked VII $^{\text {th }}$ as per their weighted mean score of 1.61 and 'Psychological : Fruits and vegetables produce not be eaten because of religious taboos (Garlic, Onion)' ranked VIII ${ }^{\text {th }}$ with weighted mean score of 1.21 .

\section{Secondary causes of losses}

Table 2 reveals that 'Inadequate storage facilities' was ranked $I^{\text {st }}$ and was found with serious causes according to weighted mean score of 2.61 and 'Lack of adequate containers 
for the transport and handling of perishable products' ranked $\mathrm{II}^{\text {nd }}$. 'Inadequate harvesting, packaging and handling skills' was ranked III $^{\text {rd }}$ as per the weighted mean score of 2.57, and 'Inadequate transportation to market' was ranked $\mathrm{IV}^{\text {th }}$ as per its weighted mean score of 2.36 .

The data also revealed that the cause 'Inadequate refrigerated storage facilities' was ranked $\mathrm{V}^{\text {th }}$ according to weighted mean score of 2.24, 'Bumper crops can overload the postharvest handling system or exceed the consumption need and cause excessive wastage' was ranked $\mathrm{VI}^{\text {th }}$ as per weighted mean score of 2.05, while 'Inadequate drying equipment or poor drying season' and 'Traditional processing and marketing systems could be responsible for high losses' were major secondary causes of losses in value addition of horticultural and vegetable crops and they were ranked VII ${ }^{\text {th }}$ and VIII ${ }^{\text {th }}$ as per their weighted mean score of 1.95 and 1.79, respectively. Kiresur and Kumar (1998) revealed that absence of storage facilities was the major problem expressed by 91.23 per cent of onion growers. Vasudev and Choudhary (1999) observed that the lack of grading facilities, absence of market information and spoilage and malpractices were the major problems in production and marketing of tomato in the regions of Andhra Pradesh. They concluded that providing these facilities could improve the marketing efficiency and would help the farmers in realizing better prices.

\section{Losses at site}

Table 3 shows that 'Harvest: The separation of the commodity from the plant that produced it' was ranked $\mathrm{I}^{\text {st }}$ as per weighted mean score of 2.39, and 'Transportation: used to convey produce from the point of production to the ultimate point of consumption' was found serious cause according to weighted mean score of 2.32 and it was ranked $\mathrm{II}^{\text {nd }}$.
'Preparation: The preliminary separation or extraction of the edible from the non-edible portion e.g., the peeling of fruits and vegetables, etc.' was ranked III $^{\text {rd }}$ as per its weighted mean score of 2.00. The data also revealed that the constraint 'Processing: is the conversion of edible food into another form more acceptable or more convenient to the consumer' was ranked $\mathrm{IV}^{\text {th }}$ according to weighted mean score of 1.87 and 'Preservation: is the prevention of loss and spoilage of produce' was ranked $\mathrm{V}^{\text {th }}$ as per weighted mean score of 1.58. Pamer et al., (1994) reported that spoilage of vegetable was the major problem faced by 68.46 per cent vegetable growers during marketing of vegetable due to not adoption of post-harvest management practices, following by losses due to inadequate transportation facilities reported by 23.81 per cent of vegetable growers.

\section{Constraints related to effect of environment on horticultural and vegetable produce}

It was found from Table 4 that 'Temperature : In general, the higher the temperature, the shorter the storage life of crops' was ranked I ${ }^{\text {st }}$ as per weighted mean score of 2.66 and 'Heavy incidence of disease' was found serious constraint according to weighted mean score of 2.46 and it was ranked II $^{\text {nd }}$. 'Hail damage: Affects the physical quality of produce and increases the incidence of diseases' was ranked III $^{\text {rd }}$ as per the weighted mean score of 2.36 .

The data also revealed that the constraints 'Frost damage : Causes burning in the foliage of vegetables' was ranked $\mathrm{IV}^{\text {th }}$ according to weighted mean score of 2.22 , while 'Chilling injury : Chilling injury can deteriorate the quality and spoil the fruits' was ranked $\mathrm{V}^{\text {th }}$ as per weighted mean score of 2.17, and 'Humidity : Stored under conditions of high relative humidity to prevent moisture loss and 
wilting' and 'Physical damage: Tissues discoloration due to pathogen growth' were considered the major cause of noise pollution and they were ranked $\mathrm{VI}^{\text {th }}$ and $\mathrm{VII}^{\text {th }}$ as per their weighted mean score of 2.07 and 2.01, respectively.

Table 4 also revealed that 'Light: Colour and morphological change (green potato)' was ranked VIII ${ }^{\text {th }}$, with weighted mean score of 1.63. The data also revealed that 'Gravity : Morphological changes (fruit bending)' was ranked IX $^{\text {th }}$, with weighted mean score of 1.48, whereas 'Pathogen : Fungi, bacteria and viruses' was found one of the serious constraints of value addition in horticultural and vegetable crops and ranked $\mathrm{X}^{\text {th }}$ according to their weighted mean score of 1.46. Chand et al., (2002) reported that insufficient moisture in soil, occurrence of frost, more infestations of insect-pests and diseases and inaccessibility of suitable implements were some of the major constraints as perceived by the farmers in adoption of improved mustard technology.

Table.1 Primary causes of losses

\begin{tabular}{|c|c|c|c|c|}
\hline $\begin{array}{l}\text { S. } \\
\text { No. }\end{array}$ & Statements & $\begin{array}{c}\text { Total } \\
\text { weighted } \\
\text { score }\end{array}$ & $\begin{array}{c}\text { Weighted } \\
\text { mean } \\
\text { score }\end{array}$ & $\begin{array}{c}n=180) \\
\text { Rank } \\
\text { Order }\end{array}$ \\
\hline 1. & Biological : Consumption of produce by rodents, birds, monkeys & 495 & 2.75 & I \\
\hline 2. & Microbiological : Damage to stored produce by fungi and bacteria & 423 & 2.35 & II \\
\hline 3. & $\begin{array}{l}\text { Mechanical : Bruising, cutting' excessive pooling or trimming of } \\
\text { horticultural products are causes of loss }\end{array}$ & 399 & 2.21 & III \\
\hline 4. & $\begin{array}{l}\text { Chemical : Contamination of produce with harmful chemicals such } \\
\text { as pesticides or obnoxious chemicals such as lubricating oil }\end{array}$ & 373 & 2.07 & IV \\
\hline 5. & Physical : Excessive or insufficient heat or cold can spoil foods & 349 & 1.93 & $\mathrm{~V}$ \\
\hline 6. & $\begin{array}{l}\text { Biochemical reactions : A number of enzyme-activated reactions } \\
\text { can occur in foods in storage }\end{array}$ & 342 & 1.90 & VI \\
\hline 7. & $\begin{array}{l}\text { Physiological : Natural respiratory losses e.g. ethylene results in } \\
\text { premature ripening of certain crops }\end{array}$ & 290 & 1.61 & VII \\
\hline 8. & $\begin{array}{l}\text { Psychological : Fruits and vegetables produce not be eaten because } \\
\text { of religious taboos (Garlic, Onion) }\end{array}$ & 218 & 1.21 & III \\
\hline
\end{tabular}

Table.2 Secondary causes of losses

\begin{tabular}{|c|c|c|c|c|}
\hline & & & \multicolumn{2}{|c|}{$(n=180)$} \\
\hline $\begin{array}{l}\text { S. } \\
\text { No. }\end{array}$ & Statements & $\begin{array}{c}\text { Total } \\
\text { weighted score }\end{array}$ & $\begin{array}{l}\text { Weighted } \\
\text { mean score }\end{array}$ & $\begin{array}{l}\text { Rank } \\
\text { order }\end{array}$ \\
\hline 1. & Inadequate storage facilities & 471 & 2.61 & I \\
\hline 2. & $\begin{array}{l}\text { Lack of adequate containers for the transport and handling of } \\
\text { perishables products }\end{array}$ & 465 & 2.58 & II \\
\hline 3. & Inadequate harvesting, packaging and handling skills & 463 & 2.57 & III \\
\hline 4. & Inadequate transportation to market & 426 & 2.36 & IV \\
\hline 5. & Inadequate refrigerated storage facilities & 404 & 2.24 & V \\
\hline 6. & $\begin{array}{l}\text { Bumper crops can overload the post-harvest handling system } \\
\text { or exceed the consumption need and cause excessive wastage }\end{array}$ & 369 & 2.05 & VI \\
\hline 7. & Inadequate drying equipment or poor drying season & 351 & 1.95 & VII \\
\hline 8. & $\begin{array}{l}\text { Traditional processing and marketing systems can be } \\
\text { responsible for high losses }\end{array}$ & 323 & 1.79 & VIII \\
\hline
\end{tabular}


Table.3 Losses at site

\begin{tabular}{|c|l|c|c|c|}
\hline $\begin{array}{c}\text { S. } \\
\text { No. }\end{array}$ & Statements & $\begin{array}{c}\text { Total weighted } \\
\text { score }\end{array}$ & $\begin{array}{c}\text { Weighted } \\
\text { mean score }\end{array}$ & $\begin{array}{c}\text { Rank } \\
\text { order }\end{array}$ \\
\hline $\mathbf{1 .}$ & Harvest : The separation of the commodity from the plant that produced it & 431 & 2.39 & I \\
\hline $\mathbf{2 .}$ & $\begin{array}{l}\text { Transportation : used to convey produce from the point of production to the } \\
\text { ultimate point of consumption }\end{array}$ & 418 & 2.32 & II \\
\hline $\mathbf{3 .}$ & $\begin{array}{l}\text { Preparation : The preliminary separation or extraction of the edible from the } \\
\text { non-edible portion, e.g., the peeling of fruits and vegetables }\end{array}$ & 361 & 2.00 & III \\
\hline $\mathbf{4 .}$ & $\begin{array}{l}\text { Processing : is the conversion of edible food into another form more } \\
\text { acceptable or more convenient to the consumer }\end{array}$ & 337 & 1.87 & IV \\
\hline $\mathbf{5 .}$ & Preservation : is the prevention of loss and spoilage of produce & 286 & 1.58 & V \\
\hline
\end{tabular}

Table.4 Constraints related to effect of environment on horticulture and vegetable produce

\begin{tabular}{|c|l|c|c|c|}
\hline \multicolumn{1}{|c|}{ Statements } & $\begin{array}{c}\text { Total } \\
\text { Noighted } \\
\text { score }\end{array}$ & $\begin{array}{c}\text { Weighted } \\
\text { mean } \\
\text { score }\end{array}$ & $\begin{array}{c}\text { Rank } \\
\text { order }\end{array}$ \\
\hline $\mathbf{1 .}$ & $\begin{array}{l}\text { Temperature : In general, the higher the temperature the shorter the } \\
\text { storage life of crops }\end{array}$ & 479 & 2.66 & I \\
\hline $\mathbf{2 .}$ & Heavy incidence of disease & 443 & 2.46 & II \\
\hline 3. & $\begin{array}{l}\text { Hail damage : Affects the physical quality of produce and increases the } \\
\text { incidence of diseases }\end{array}$ & 426 & 2.36 & III \\
\hline 4. & Frost damage : Causes burning in the foliage of vegetables & 401 & 2.22 & IV \\
\hline $\mathbf{5 .}$ & $\begin{array}{l}\text { Chilling injury : Chilling injury can deteriorate the quality and spoil the } \\
\text { fruits }\end{array}$ & 392 & 2.17 & V \\
\hline 6. & $\begin{array}{l}\text { Humidity : Stored under conditions of high relative humidity to prevent } \\
\text { moisture loss and wilting }\end{array}$ & 374 & 2.07 & VI \\
\hline 7. & Physical damage : Tissues discoloration due to pathogen growth & 362 & 2.01 & VII \\
\hline $\mathbf{8 .}$ & Light : Colour and morphological change (green potato) & 294 & 1.63 & VIII \\
\hline 9. & Gravity : Morphological changes (fruit bending) & 267 & 1.48 & IX \\
\hline $\mathbf{1 0 .}$ & Pathogen : Fungi, bacteria and viruses & 263 & 1.46 & X \\
\hline
\end{tabular}

Table.5 Constraints regarding cultural practices

\begin{tabular}{|c|l|c|c|c|}
\hline S. No. & Statements & $\begin{array}{c}\text { Total weighted } \\
\text { score }\end{array}$ & $\begin{array}{c}\text { Weighted } \\
\text { mean score }\end{array}$ & Rank order \\
\hline $\mathbf{1 .}$ & $\begin{array}{l}\text { Water excess increases the susceptibility to physical } \\
\text { damage in some products }\end{array}$ & 376 & 2.08 & I \\
\hline $\mathbf{2 .}$ & $\begin{array}{l}\text { Water stress (from severe to moderate) is related with } \\
\text { irregular ripening, reduced fruit size, increased total solid } \\
\text { soluble salt contents and acidity }\end{array}$ & 353 & 1.96 & II \\
\hline $\mathbf{3 .}$ & $\begin{array}{l}\text { Several physiological disorders are associated with } \\
\text { nutritional deficiencies }\end{array}$ & 351 & 1.95 & III \\
\hline $\mathbf{4 .}$ & $\begin{array}{l}\text { Nutritional condition : Calcium related with long post- } \\
\text { harvest; high nitrogen related with shorter post-harvest life } \\
\text { due to high susceptibility to mechanical damage, } \\
\text { physiological disorders and decay }\end{array}$ & 336 & 1.86 & IV \\
\hline
\end{tabular}




\section{Constraints regarding cultural practices}

Table 5 reveals that 'Water excess increases the susceptibility to physical damage in some products' was ranked It ${ }^{\text {st }}$ as per weighted mean score of 2.08 and 'Water stress (from severe to moderate) is related with irregular ripening, reduced fruit size, increased total solid soluble salt contents and acidity' was found serious constraint according to the weighted mean score of 1.96 and it was ranked $\mathrm{II}^{\text {nd }}$. 'Several physiological disorders are associated with nutritional deficiencies' was ranked $\mathrm{III}^{\mathrm{rd}}$ as per the weighted mean score of 1.95 and 'Nutritional condition : calcium related with long post-harvest; high Nitrogen related with shorter post-harvest life due to high susceptibility to mechanical damage, physiological disorders and decay' was ranked $\mathrm{IV}^{\text {th }}$ as per its weighted mean score of 1.86 .

In conclusion, the present study was conducted in Haryana state and two districts Hisar from southwest and Sonipat from northeast were selected, purposively. From each district, three blocks were selected randomly. Further, three villages were selected from each block making a total of 18 villages. From each village, ten farmers were selected randomly, making a total sample of 180 farmers. Hence, one hundred eighty farmers were interviewed for the study. It was found that 'Biological: Consumption of produce by rodents, birds, monkeys', 'Inadequate storage facilities', 'Harvest: The separation of the commodity from the plant that produced it', 'Temperature: In general, the higher the temperature, the shorter the storage life of crops' and 'Water excess increases the susceptibility to physical damage in some products' was ranked I ${ }^{\text {st }}$. To reach the results aggregates total was calculated for each statement separately and on the basis of calculated scores, mean scores and mean score percentage were obtained which were ranked according to their maximum to minimum mean score percentage for assessing the knowledge level of the farmers.

\section{References}

Atanda, S. A., Pessu, P. O., Agoda, S., Isong, I. U., \& Ikotun, I. (2011). The concepts and problems of post-harvest food losses in perishable crops. African Journal of Food Science, 5(11), 603-613.

Chand, S., Dangi, K. L. and Bansal, V. (2002). Constraints in adoption of improved mustard production technology. Indian Journal of Extension Education, 37 (1\&2): 91-92.

Kapoor, R., 2012. Urban agriculture for food security. Business line, Oct.16

Khalache, P. G. and Khaire, P.R. (2007). Knowledge level and training needs of fig growers in Pune district. Internat. $J$. Agric. Sci, 3 (1): 261-264.

Kiresur, V. R. and Ganeshkumar, N. (1998). Impact of regulation on vegetable marketing in Indian-A case study in Dharwad district of Karnataka state. Indian J. Agric. Market, 2 (1): 23-30.

Subbanarasaiah, N., 1991.Marketing of Horticultural Crops in India. Delhi, Anmol Publishing Co.

Vasudev, N. and Choudhary, K. R. (1999). Marketing of tomato in Andhra Pradesh. Indian J. Agric. Mktg, 13 (2): 53.

\section{How to cite this article:}

Sonia Rani, P.S. Shehrawat and Joginder Singh Malik. 2019. Constraints Faced by Farmer's Towards Value Addition in Horticulture and Vegetable Crops. Int.J.Curr.Microbiol.App.Sci. 8(10): 2018-2024. doi: https://doi.org/10.20546/ijcmas.2019.810.235 